\title{
Performance Management Practices and Employee Productivity at State Department of Labour, Kenya
}

\author{
Ogolla Carol \\ Oluoch Mercy Florah \\ University of Nairobi \\ Kenya
}

\begin{abstract}
Performance Management practices are significant in the assessment of the total production by an organization. It is critical to evaluate each employee's skills and knowledge, to secure increased productivity in the work place that reverberates to achieve organizational goals. Similarly, the feedback for performance of employee is significant in learning as well as ensuring that the employees understand the required standards, as compared to his or her performance. This study assessed the effect of performance management practices on employee productivity at the State department of Labour. The performance management practices were comprised of employee's appraisal as well as provision of feedback on employee's performance. The study undertook a descriptive research design, where primary data was collected through structured questionnaires on the targeted population of middle and lower level employees. A population of 278 respondents was identified and random stratified sampling was undertaken to come up with a sample size of 68 respondents. 46 questionnaires were answered and returned, which comprised of 67.6\% response rate. Data analysis was done by the use of mean, percentages, standard deviation and regression analysis where the effect of independent variables; employee appraisal, and employee performance feedback was determined on employee productivity. The study found that there was a strong positive correlation of both employee appraisal and employees performance feedback on employee productivity. The study therefore recommended that organizations to undertake both appraisal for their employees as well as offer feedback on their performance as it increased the productivity of the employees.
\end{abstract}

\subsection{Background of the Study}

Performance management entails actions that ensure that the firm's goals are achieved constantly in an efficient and valuable way. Fowler (1990) observes that management of performance ensures that a firm is in a position to attain the best outcome. On the other hand The Institute of Personnel Management (2002)undertakes performance management as an approach that relate to many organizations' activities, positioned in the framework of procedures, traditions, style and system of communication of the human resource . Baron and Armstrong (2007) viewed performance management as a process that involved a decisive approach that help in improving the firms productivity and employees by uplifting employee performance through teamwork and personal capabilities. There are people who argue that by using performance management practices that involves recruitment of employees, training and developing them, employee's appraisal and developing a feedback system can increase the knowledge, skills and the capability of a firms employee meanwhile enhancing their motivation, cutting down malingering and improving maintenance of top performing employees and their productivity. Productivity measure the workers efficiency, it can be determined by the results that employee gives at certain duration of time. Normally, certain employee productivity is measured in relation to results expected if an average employee undertook a similar task. Since achievement of a firm is seen though it work force, productivity of employees is of much concern to any business to assess therefore performance management in any given way check on how individuals are motivated and to what level are they of use to a firm. This research is going to have a clearer view of employees' appraisal and feedback on production.

The goal setting and the expectancy theory influences this study. Edwin Lock, the founder of this theory said that when a firm or individual sets difficult goals, there is a better performance. There is always a decrease in performance of an individual and a firm when performance goals are easy to achieve (Lock \& Latham 2006). This theory developed in a study of psychology of a firm. Organizations goals and aids in improvement of an action plan which intended to help individuals and firms. Therefore, this assists in creating an important element of individual development and literature management. It is also clear that setting of goals increases the productivity in a firm as the theory of goal setting entails all aspect of having efficient firm (Koppes, 2014). 
Expectancy theory on the other hand was based through the works of Vroom (1965) where he suggested that people conduct themselves in a certain way since they are motivated by desirable outcomes. The performance of an individual need to be aligned to his/her personal goals by the firm in order to enhance success for the organization (Salamanet al. 2005). The motivation that makes someone to conduct him/herself in a certain way over the forms of conduct is purely because of personal goals, or individual expectations. This expectation concerns their preferred behavior (Oliver 1974; Salaman et al 2005).

The reorganization of government in May 2016 necessitated the establishment of the State Department of Labour, which stemmed from the Ministry of Labour and Social Protection. Prior to the establishment of the department, it existed in various forms since the independence of the country in 1963; the two ministries that hosted the department were Ministry of East African Community and the ministry of Labour and Social Services. The main goal for the state department of Labour is to ensure that the country has attained economic development through the promotion of harmonious industrial relations, ensures that there is strict adherence to safety and health standards at the work places; industrial training; planning for human resource development and utilization, productivity management, as well as registration and regulation of trade unions. The State department of Labour has five technical departments that assist in implementation of goals and objectives. There are a number of bodies allied to the state department that are vital in execution of duties for the ministry. Autonomous Government Agency (AGA), The National Social Security Fund (NSSF), National Industrial Training Authority (NITA) and National Employment Authority (NEA), National Labour Board and National Council for Occupational Safety and Health (NACOSH) (State Department for Labour, 2019).

The strategic objective of this department is to encourage a balanced industrial labour relation, social dialogue and labour practices, which are fair, and the second objective is to promote the basic values and rights at work. The department vision is to ensure it is the leading organization in the promotion of good work for everyone, its mission is to plan, direct and put into practice sound labour and employment guidelines for the achievement of social justice, business peace, and ensuring there is a good environment for creation of employment. The state department of labour ensures that everyone is in a working environment that is free from any sexual harassment, no employment discrimination by ensuring that labour officers encourage equality of chance, no assistance will be needed in recruiting, good employee remuneration, therefore this promote high employee productivity (Baron\& Armstrong, 2004).

\subsubsection{Performance Management Practices}

Performance management practices are systematic ways of communicating to employees on what performance and productivity parameters are expected of them (Marsor, 2011). In different studies conducted by Bead well (2007) and thereafter another study conducted by Jackson (2009), they envisioned performance management as activities such as knowing what goals are and how they should be measured, performance evaluation, performance feedback, incentivebased performance, planning of career, motivation, training and development. The attributes of defining measurable individual goals for employees, performance appraisal, feedback, incentives tagged to performance, planning as well as motivation and training and development. There are put in place so as to provide better outcome by having a better knowledge and management of various performances by employees as compared to the set goals. These goals and objectives offer direction, control, encourage and examine personal performance. This improves the choosing of goals that are precise, achievable, as well as goals owned by the employees. In order for employees to own these goals, then the organizational goals aligned to the employees' individual goals. This reduces conflicts in the organization and increases the speed with which the organizational goal are achieved (Armstrong, 2008).

Appraisal of employees is vital as it helps in identifying individual contribution towards achievement of organizational goals and the strength as well as the weakness of individual employees. It therefore creates an avenue that makes it possible to focus on improving employees' weaknesses and encouraging the development of employees' strengths. Appraisal is also important as it provides a platform that can be used to reward employees depending on individual contribution towards achievement of the organizational goals. A study presented by Bloom et al. (2017) on improving employee performance through appraisal and coaching; concluded that only through strong and effective management practices being in place is when the organization is able to replicate some code of conduct and harmonize on the diversity of their work force. In relation to the culture, social status, economic position, region and diversity as evidenced in multinational firms and large corporations. Feedback is the reflection on past performance against the objectives set and results given by the supervisor or manager to the employee. It is the process by which managers as well as the supervisors have the opportunity to reflect on the performance by employees, discuss the gains as well as the shortfalls, and available opportunities that can be exploited in future to enhance performance (Jackson \& Schuller, 2012). Performance feedbacks offers a conversation which motivates employees to have a better knowledge on what they are doing, offers coaching, feedback and gives a clear expectation on development of a career (Brown \&Benson 2013). Performance feedback makes sure that individual is certain on their objective and management process. 
The process needs experts competent to understand the required performance and the performance achieved. The expert is therefore in position to determine the performance gap and advise on alternative course of actions to be carried to ensure that the employees obtain reliable feedback, with a high level of credibility (Berry, 2003). Providing feedback to employee is acknowledge as an important practice that aspires self-development and productivity of employee that are helpful for the victory of the firm (Baruch, 2006)

\subsubsection{Employee Productivity}

Gummesson (1998) defines employee productivity as the ability of a worker to produce quality outputs with limited inputs. Sells et al. (2006) further suggests that one of the major components that affects the profitability of an organization is employee productivity, as it determines the level of production that needs to be reported by the organization with its level of inputs. Human services represent one of the key components of production factors and cannot be ruled out in any organization. Employees who are deemed productive are able to transform limited inputs to high quality output that generates revenue for the organization. This therefore warrants organization to be tasked with the responsibility of motivating the workforce to achieve desired goals (Stark, 2018). Organizations are concerned on how they can best maintain a sustainable performance and achieve best results from their employees by exploring on the best alternative solutions to engage, develop teamwork and encourage employees to give their best input in what they work in (Walters, 2015). Not only financial rewards are deemed the best motivator towards enhanced employee productivity but also non-financial incentives. Inkinen (2016) presented an oversight, which reviewed the effectiveness of performance management and organizational performance.

\subsubsection{State Department for Labour}

The government of Kenya faced much reorganization in the year 2013 after the country's top leadership changed in the year 2012. There was formation of ministries, of which the state department for Labour was placed under the newly formed ministry of Labour and Social Protection. It combined the former Ministry of Labour and former Ministry of Gender, Children and Social Development that were in existence since independence. The State Department for Labour is currently led by Eng. Peter Tum with the vision to promote and enhance competitiveness in the workforce and increased just system in the society. They aim to increase productivity by empowering the vulnerable groups. The State Department of Labour contributes to the nation's GDP, by ensuring that there exists a harmonious relation in the working population, safety and health measures observed in places of work, as well as establish mechanism for ensuring that employees are empowered, trained, promoted and better remunerated. The Department also ensures that it undertakes productivity management, and helps in the planning for development of human resources and human capacity through provision of social security and registration of the employees in trade unions.

State Department for Labour constitutes of five departments that are tasked with the mandate to ensure that they achieve the mission and vision of the Ministry. It is from this background, that the State Department for Labour promotes training and development of employees and ensures that it pays attention towards ensuring that the health and safety for all employees is regarded with utmost urgency by all the organizations. It also ensures that all the hurdles that may compromise on the productivity of employees are attended to accordingly.

\subsection{Research Problem}

Performance management practices studies show that a firm's productivity is simply a function of human resource practices it employs. There is a unique global change in organizational management over the few years. Performance management has become a crucial firm process and it has increased pressure to achieve high performance levels, and raised the bar for various work practices (Armstrong, 2009). A motivated work force also assists in reduction of turnover rate and improves the productivity in the firm. Hence successful performance management has essential part in human resource. Organization's human resource practitioners are being forced to rethink on the appropriate model to adopt to build a sustainable employee productivity as well meeting the institution's demand. This does not come easy as the organizations are forced to embrace and develop the capacities of its workforce, to retain competitive edge over competitors. Key consideration of employee management entails defining performance agreements, appraisals, performance feedback, rewards, training and growth. These aids in specification of the expected organizational goals, support to the management personnel and democratic style of leadership that supports all cadres of management.

The State Department for labour was established to identify ways in which employees would be empowered in obtaining adequate training, good remuneration and conducive working conditions among other activities that are geared towards enhancing productivity. This is done through formulation and execution of the National Labour Legislation and procedures through the National Labour Board and sectoral wages councils as well as the National Tripartite Consultative Council. The Department is also responsible for operationalizing the tripartite mechanism in managing labour matters through a tripartite discussion, which entails meeting between employees, employers and government legislature. 
The department vision is to assist in being the leading organization in the promotion of good work for everyone and it mission is to plan, direct and put into practice sound labour and employment guidelines for the achievement of social justice, business peace and ensuring there is a good environment for creation of employment (Baron\& Armstrong, 2004). According to Muriithi (2015), the State department has been accussed of harboring corruption and internal wrangles among various leaders. This may therefore compromise the ability of the State department of labour to execute its mandate satisfactory. The NSSF corruption scandals such as Ksh 13 billion housing scandal, Ksh 1.6 billion shares scandal and leadership wrangles that led to resignation of the board chairman are some of the incidences that have dented the success stories in the ministry. The state department for labour therefore struggles to execute its mandate and deal with all the fanfare that arise from corruption related dealings. The performance and productivity of employees are therefore compromised and may not be supported to the extent they would have deserved if the ministry was scandals-free.

Inkinen (2016) studied practices for performance management, knowledge management and firm performance in US. This was necessitated by the need to rank knowledge management as an emerging issue to new management models with a systematic review process. The findings demonstrated that knowledge management as part of performance management practices had a positive and significant association to organization performance. According to Hanaysha (2016) presentation on effects of performance management aspects of teamwork, employee training and employee empowerment on organizational commitment in Malaysia. The study sampled 242 employee's university employees and established that employee empowerment at workplace was significantly related to organizational commitment.

A study presented by Okeke, Onyekwelu and Akpua (2019) that was undertaken in South East Nigeria, with the view of establishing the impact of performance management on the productivity of its employees. The study specifically considered how 360-degree feedback appraisal, self-assessment, performance review and evaluation has on employee productivity using a sample size of 366 respondents. Findings indicated a 360-degree feedback appraisal had a positive and significant influence on the productivity of employees.

Locally, a study presented by (Murithi, 2015) relating to empirical investigation of continuous improvement relating to performance based compensation emphasized on the need for the leaders to champion in effective and efficient platforms meant to uplift organizations and employees through training, recognition and reward system. Omusebe and Musiega (2013) presented a study relating to strategy to effect performance management to improve performance and productivity of organizational employees in Kenyan banks. The study indicated that performance appraisal system is paramount in undertaking HRM (Human Resource Management) and must be adhered to if organization is to achieve and make use of it human resources.

\subsection{Literature Review}

According to Cook, (2014), performance appraisal refers to the process of identifying, examining, measuring and growing performance of employee in the firm. This gives an embedment to the key composition needed for an appraisal to take effect in performance management and performance of employee. The criterion of gauging the performance appraisal is very relevant given the significant components enshrined in it to help examine employee performance related criteria. The examining factor for employee appraisal observation is aligned to the role that supervisor have in assessing and molding employees in a win scenario to register higher productivity. The supervisor has the duty of translating the observable features in an employee workplace administration to judgmental ratings relevant and comparable across the organizations.

Kim (2016), presented a study titling the effect on performance evaluation system implied to civil service performance to have a better pay. The study targeted human resource directors in the United States after civil reforms in performance appraisal of 30 state agencies. The study was motivated by the need to have perceived justice of evaluation of performance and established out those macroeconomics factors on politicization of perceived evaluation of employee productivity was unhelpfully and considerably associated with the pay for usefulness of performance The aspect of the importance of appraisal was of relevant and considerably correlated to pay for usefulness of performance. The pay for performance was found to be affected by variation in demographic features example; gender, age, level of experience and education in state differences.

Singh and Rana (2015) presented a study relating to influence of performance appraisal on organizational commitment to bank employees in India. The study randomly sampled 172 employees from 10 public sector financial institutions. This was because of establishing how appraisal influences productivity given that the model has been the oldest and ubiquitous practices of employee management in organizations when assessing their performances. This research study came into conclusion that performance evaluation had a helpful association to the firm's obligations of the employees. 
Mostly, the attentiveness of the performance appraisal, fairness in the appraisal procedures and payment associated with performance practices were extensively determined by the firm's commitment of the financial institutions employees. A study presented by Owili and Isaac (2018) on organizational justice in performance appraisal system and work performance among listed financial institutions came into conclusion that there is a great importance in the productivity of employee in a good way influenced by performance appraisal criteria. Appropriate appraisal is linked to effective job administration, promotion, rewards, and bonus and salary increments. Further, performance appraisal has been associated to the distributive justice with relevant impact on how relation in appraisal improves performance of the employees. Providing favorable working conditions by the employer to the employees has a positive connotation to drive to do best and register good productivity as proposed by (Jackson \& Schuller, 2012).when an organization satisfies its employees ,they become very helpful and customer friendly, hence leading to efficient services and high return. This spills to customer satisfaction, employee responsiveness, innovation in the organization and product quality. At the end, performance appraisal plays a role in employee's commitment resulting to increase in revenue growth (Erdogan, 2012).

The nature of responding to performance feedback between the organizational supervisors and the employees has an important effect on the firm's productivity and employee performance. Having regular updates relating to the outcome of the employees and addressed by the immediate managers on the work activities, way forward and areas of adjustment bring teamwork in the organization setup. The performance feedback greatly offers discussions, which assist to understand employee progress gain education and response, clarify prospect and career expansion (Brown \& Benson, 2013).

Enhancing employee productivity through performance feedback is acknowledged in the concept of having clear specification and flow of information in top to downward communication mostly when the seniors are setting rules, delegating tasks, passing message that needs clarification and advising seniors. Conventionally, down to top approach model of communication whereby the employees are seeking to have their issues heard, airing complaints and seeking clarifications on areas that seem not clear. Such a model revolves around performance feedback that helps to catapult organization when put in consideration to relevant issues. According to (Caruth, 2018), the need for clear-based performance feedback to the employees must have a workflow for tracing on the feedback sessions. This is very relevant in detecting mistakes and immediately setting up remedial steps with less impact to the organization. Providing employees with the right and decisive feedback is regarded as a crucial avenue towards fulfilling the organization objectives (Baruch, 2016).

Evidently, successful performance feedback depends on how the employees will accept process and the reactions generated in the guide when intending to have such critical issues to whether those in the process are satisfied or dissatisfied with the feedback they receive. A study presented by Bernstein and $\mathrm{Li}$ (2017) about employee seeing where they stand in form of performance feedback to performance transparency with serious concerns in the information age. The form of advanced technology being used in some of the organizations are tracking on the employees' activities, generating and reporting the performance led data without the involvement of the traditional manager or supervisor. The study integrated a field data to track fifty large corporations in service sector by replacing performance feedback reviews with high tech system generated performance data on the employee's productivity. The study findings indicated existence of a vertical association in supervisor supported and horizontal relation in social comparison. The study concluded by emphasizing the need to substitute for managers and informal social comparison with transparent data generated feedback as there is not lenience or personal delightful errors.

\subsection{Conceptual Framework}

Conceptual framework represents diagrammatic information that illustrates the nature of the association of independent variables and those of dependent variable. Conceptualization model helps to have an abstract figure out of the determinant variables being; performance appraisal and performance feedback verses the response variable on employee productivity as shown in the figure 2.1 below. Figure 2.1: Conceptual Model

Independent Variable

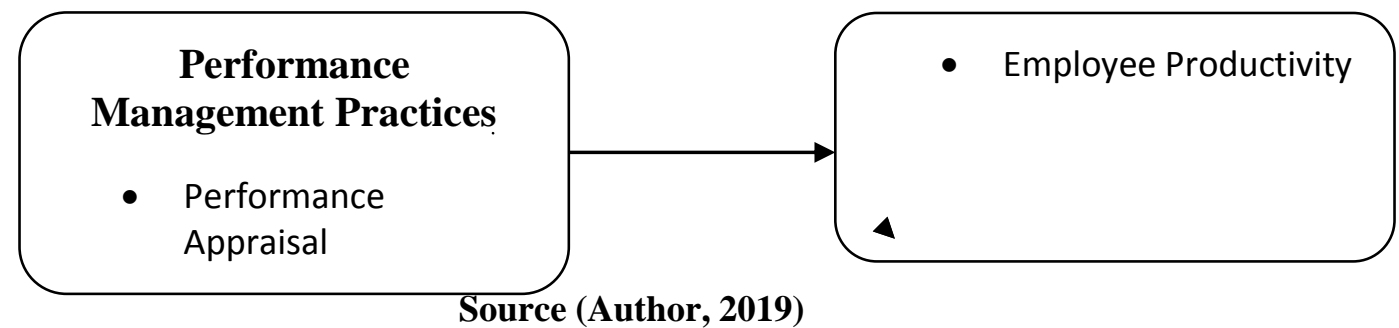




\subsection{Research Design}

Research design is a well-developed plan that gives a guide on how data should be interpreted, analyzed and gathered results via a dialect and inference on data relations (Mugenda, 2012). The research uses the explanatory design of research inform of a survey and outline on the association that exist among determinant and response variables for the study by inferring on when, where, what, why and how.

\subsection{Target Population}

Mugenda (2012) stated that right population involves all set of people, elements, and groups or items that that has certain characteristics and the researcher wants to generalize the information about them. The target population in the study involved the employees from top management cadre, middle level management and lower management cadre. The mix of all the categories of the employees helps in understanding underpinning issues to all employees in a fair and justifiable manner.

Table 3.1 Target Population

\begin{tabular}{lll}
\hline Category & Target Population & Percentage presentation \\
\hline Middle Management Level & 115 & $41.37 \%$ \\
Lower Management Level & 163 & $58.63 \%$ \\
\hline Total & $\mathbf{2 7 8}$ & $\mathbf{1 0 0 \%}$ \\
\hline Note. Data for management Structure & at State Department Adapted from HR State Department of Labour data
\end{tabular}
(2019).

\subsection{Sampling Size}

A sample is a subject that is categorically selected from the target population with salient features for investigation (Mugenda, 2012). According to Garg and Kothari (2014) stated that a sample must be at least $20 \%$ of the target population is acceptable for the study. The basic idea is that by selecting a sample, conclusions can be drawn about the entire population. A proportionate stratified sampling will be used and the respondent from every subgroup will be selected for inclusion in the sample size by selecting $20 \%$ of the target population.

Table 3.2 Sample Size

\begin{tabular}{llll}
\hline Cadre & Target Population & $\begin{array}{l}\text { Sample } \\
\text { Population }\end{array}$ & $\begin{array}{l}\text { Percentage of } \\
\text { sample population }\end{array}$ \\
\hline Middle Management Level & 115 & 27 & $39.7 \%$ \\
Lower Management Level & 163 & 41 & $60.3 \%$ \\
\hline Total & $\mathbf{2 7 8}$ & $\mathbf{6 8}$ & $\mathbf{1 0 0 \%}$ \\
Note. Data for management Structure at State Department Adapted from HR State Department of Labour data
\end{tabular}
(2019).

\subsection{Data Collection}

Data collection methods are structured tools, which collect respondent's information. The study will use questionnaire that will be developed to capture on the demographic information of the respondents and the descriptive analysis of the study variables relating to performance appraisal, reward system and performance feedback. Questionnaires were used for data collection due to the convenience in their administration, easy to collect data, less costly and little biases.

\subsection{Data Analysis}

The questionnaire statement will be extracted and interpreted in demographic information that deals with age, gender and work experience and education level. The descriptive response data will be examined in terms of occurrences, percentage, mean, standard deviation and variance while inferential statistics will be generated to specify on nature of correlations, coefficient of determination, analysis of variance and regression models

Data Analysis and Presentations of the Findings

Table 4.1 Response rate

\begin{tabular}{llll}
\hline Category & Target & Response & Non response \\
\hline Middle management & 27 & 12 & 15 \\
Lower management & 41 & 34 & 7 \\
\hline Total & 68 & 46 & 22 \\
\hline
\end{tabular}

The study response in table 4.1 above showed that out of 68 sample size, 46 returned their questionnaire representing $67.6 \%$ response rate which was statistically acceptable for generalization. 
The rate of response ensures that the field data collection is more representative in answering the aim of the study. According to Mugenda 2012, a response rate that is above $70 \%$ gives excellent information on the representative of the sample population.

4.2 Performance appraisals and employee productivity

Descriptive Statistics

Table 4.2 Performance Appraisals and employee productivity

\begin{tabular}{|c|c|c|c|c|c|c|}
\hline & $\mathrm{N}$ & Min & Max & Mean & Std. Deviation & Variance \\
\hline $\begin{array}{l}\text { Am contented with performance } \\
\text { appraisal at State Department for Labour }\end{array}$ & 46 & 1 & 5 & 2.91 & 1.132 & 1.281 \\
\hline $\begin{array}{l}\text { Performance appraisal makes me work } \\
\text { towards company goals }\end{array}$ & 46 & 1 & 5 & 3.85 & 1.282 & 1.643 \\
\hline Implementation of performance appraisa & & & & & & \\
\hline $\begin{array}{l}\text { has a positive impact on my work } \\
\text { productivity }\end{array}$ & 46 & 1 & 5 & 3.89 & .971 & .943 \\
\hline $\begin{array}{l}\text { State Department for Labour has } \\
\text { performance appraisal implementation } \\
\text { plan }\end{array}$ & 46 & 1 & 5 & 3.91 & 1.170 & 1.370 \\
\hline $\begin{array}{l}\text { Performance appraisal makes me work } \\
\text { better than expected }\end{array}$ & 46 & 3 & 5 & 4.41 & 652 & .426 \\
\hline Valid N (listwise) & 46 & & & & & \\
\hline
\end{tabular}

The study analysis in table 4.7 was to assess on descriptive response on how performance appraisals affects employee productivity. It was evidenced that performance appraisal makes employee work well that expected as it had a mean of 4.41 and standard deviation of 0.652. The statement followed this on State Department for Labour having planned to implement performance appraisal in place, which had a mean of 3.91 and standard deviation of 1.170. Statement on the implementation of performance appraisal having a positive impact on employee work productivity was ranked third with a mean of 3.89 and standard deviation of 0.971. Performance appraisal making employees work towards company goals was ranked fourth with a mean of 3.85 and standard deviation of 1.282. Contrary, statement relating to employees being contented with performance appraisal in the organization had the lowest mean of 2.91 and standard deviation of 1.132 .

The findings of this study are in agreement with the findings by Cook (2014) who found that employee appraisal had positive impact on employee productivity. However the findings indicated a great concern on the criteria that was employed in undertaking employee appraisal, where criteria that focused on witch hunting and did not apply free and fair procedures had a direct opposite results. Cook (2014) therefore, suggested that the supervisors appraising their employees were key determinant in ensuring whether the process led to improve employee productivity or not.

Owili and Isaac (2018) found a positive correlation between the variables, while Singh and Rana (2015) in their study assessed the influence of employee appraisal on organizational commitment by employees. They agreed with provisions by Cook (2014) that the type of supervisors undertaking employee appraisals were vital in determination of whether employees were motivated to individually commit themselves to the banks.

\subsection{Performance Feedback and Employee Productivity}

Table 4.3 Performance Feedback

\begin{tabular}{|c|c|c|c|c|c|c|}
\hline & $\mathrm{N}$ & Min & Max & Mean & Std. Deviation & Variance \\
\hline $\begin{array}{l}\text { Performance feedback helps me } \\
\text { evaluate my results }\end{array}$ & 46 & 1 & 5 & 3.22 & 1.315 & 1.729 \\
\hline $\begin{array}{l}\text { My manager provides me with fair } \\
\text { performance feedback information }\end{array}$ & 46 & 1 & 5 & 3.57 & 1.455 & 2.118 \\
\hline $\begin{array}{l}\text { Performance feedback has helped me } \\
\text { to improve my productivity at } \\
\text { workplace }\end{array}$ & 46 & 1 & 5 & 3.59 & 1.166 & 1.359 \\
\hline $\begin{array}{l}\text { My organization embraces } \\
\text { performance feedback }\end{array}$ & 46 & 1 & 5 & 4.07 & .904 & .818 \\
\hline Valid N (listwise) & 46 & & & & & \\
\hline
\end{tabular}

The study assessment on the influence of performance feedback on employee productivity was established as shown in table 4.8 above. 
The findings indicated that the organization embraces performance feedback which had a highest mean of 4.07 and standard deviation of 0.904 . Secondly, statement relating to performance feedback has helped the employees to improve their productivity at the workplace had a mean of 3.59 and a standard deviation of 1.166. Thirdly, statement relating to the manager providing fair performance feedback information had a mean of 3.57 and standard deviation of 1.455. The assessment on performance feedback is relevant to employee in evaluating results had a mean of 3.22 and standard deviation of 1.315 .

These findings are related to a number of findings other studies. Jackson and Schuller (2012) in their study found out that effective feedback system after employee appraisal, enhanced productivity. Baruch (2016) noted the effectiveness of feedback mechanism in enhancing productivity as it provides direct response on areas employee need to focus to improve performance that enhances effectiveness as well as efficiency in the organization.

\subsection{Employee Productivity}

Table 4.4 Employee Productivity

\begin{tabular}{|c|c|c|c|c|c|}
\hline $\mathrm{N}$ & Min & Max & Mean & Std. Deviation & Variance \\
\hline $\begin{array}{l}\text { There is corporation and teamwork in the } \\
\text { organization }\end{array}$ & 1 & 5 & 2.78 & 1.381 & 1.907 \\
\hline Employee concentrates at the workplace 46 & 1 & 5 & 2.87 & 1.376 & 1.894 \\
\hline $\begin{array}{l}\text { Employee efficiency at workplace is very } \\
\text { high }\end{array}$ & 1 & 5 & 3.11 & 1.386 & 1.921 \\
\hline There is increased output and quality work 46 & 1 & 5 & 3.28 & 1.409 & 1.985 \\
\hline Valid N (listwise) & & & & & \\
\hline
\end{tabular}

The aspects of employee productivity was assessed and presented as shown in the table 4.9. Statement relating to increased output and quality work was ranked the best with a mean of 3.28 and standard deviation of 1.409. Statement relating to employee efficiency at work place being high came in second with a mean of 3.11 and standard deviation of 1.386. The aspect of corporation and team work in the workplace was ranked third with a mean of 2.87 and standard deviation of 1.376. Lastly, employee concentration at workplace had a mean of 2.78 and standard deviation of 1.381.

Employee productivity has been assessed in various studies to be affected by a number of factors. Kim (2016) noted that the level of performance evaluation influenced productivity in employees. The evaluation of employees was therefore encouraged, but caution was advised on evaluation as extreme measures of evaluation were found to border micro-management of employees that led to demotivation of employees. Cook (2014) associated employee productivity with performance appraisal. The type of appraisal on the employee affected either negatively or positively employees' productivity.

\subsection{Regression analysis.}

The regression model used in the study is $\mathrm{Y}=\mathrm{B} 0+\mathrm{B} 1 \mathrm{X} 1+\mathrm{B} 2 \mathrm{X} 2+\mathrm{E}$

Whereby; $\mathrm{Y}=$ employee productivity

$\mathrm{B} 0=$ constant term

$\mathrm{B} 1$ and $\mathrm{B} 2=$ coefficient of $\mathrm{X} 1$ and $\mathrm{X} 2$ respectively

$\mathrm{X} 1=$ performance appraisal

$\mathrm{X} 2=$ performance feedback

$\varepsilon=$ error term

Table 4.5: Correlations

\begin{tabular}{lllll}
\hline & & $\begin{array}{l}\text { Employee } \\
\text { productivity }\end{array}$ & $\begin{array}{l}\text { Performance } \\
\text { appraisals }\end{array}$ & $\begin{array}{l}\text { Performance } \\
\text { feedback }\end{array}$ \\
\hline Pearson Correlation & Employee productivity & 1.000 & .183 & .724 \\
& Performance appraisals & .283 & 1.000 & .346 \\
& Performance feedback & .724 & .346 & 1.000 \\
\hline
\end{tabular}

Correlation analysis was used to establish on the nature of connection between the independent variable and dependent variable. From the assessment, employee productivity had a positive association to performance appraisal with $\mathrm{r}=$ 0.283. Performance feedback had a positive association to performance of employee with $r=0.724$.

Table 4.6: Coefficient of determination

\begin{tabular}{llllll}
\hline & & & \multicolumn{2}{c}{ Std. Error of the } \\
Model & $\mathrm{R}$ & $\mathrm{R}$ Square & Adjusted R Square & Estimate & Durbin-Watson \\
\hline 1 & $.727^{\mathrm{a}}$ & .529 & .507 & .78775 & 2.556 \\
\hline
\end{tabular}


a. Predictors: (Constant), Performance feedback, Performance appraisals

b. Dependent Variable: Employee productivity

Coefficient of determination was used to test on the model of fitness of the study variables. From the analysis, it was clear that an R square of 0.529 was attained. This indicated that; performance feedback and performance appraisal had a joint significant impact to employee productivity by $52.9 \%$

Table 4.7: Analysis of variance

\begin{tabular}{lllllll}
\hline Model & & Sum of Squares & df & Mean Square & F & Sig. \\
\hline 1 & Regression & 29.936 & 2 & 14.968 & 24.120 & $.000^{\mathrm{b}}$ \\
& Residual & 26.684 & 43 & .621 & & \\
\cline { 2 - 6 } & Total & 56.620 & 45 & & & \\
\cline { 2 - 6 }
\end{tabular}

a. Dependent Variable: Employee productivity

b. Predictors: (Constant), Performance feedback, Performance appraisals

The analysis of variance was used to present on the model of significance, from the assessment a $p$ values of $0.000^{\mathrm{b}}$ was obtained which is lower that margin of error of 0.05 hence the model is statistically significant.

Table 4.8: Multilinear regression analysis

\begin{tabular}{|c|c|c|c|c|c|c|c|c|}
\hline \multirow{2}{*}{\multicolumn{2}{|c|}{ Model }} & \multicolumn{2}{|c|}{$\begin{array}{l}\text { Unstandardized } \\
\text { Coefficients }\end{array}$} & \multicolumn{3}{|c|}{$\begin{array}{l}\text { Standardized } \\
\text { Coefficients }\end{array}$} & \multicolumn{2}{|c|}{$\begin{array}{l}\text { Collinearity } \\
\text { Statistics }\end{array}$} \\
\hline & & B & Std. Error & Beta & $\mathrm{t}$ & Sig. & Tolerance & VIF \\
\hline \multirow[t]{3}{*}{1} & (Constant) & .201 & .904 & & .222 & .825 & & \\
\hline & $\begin{array}{l}\text { Performance } \\
\text { appraisals }\end{array}$ & .245 & .209 & .123 & 1.173 & .042 & .734 & 1.952 \\
\hline & $\begin{array}{l}\text { Performance } \\
\text { feedback }\end{array}$ & .956 & .142 & .750 & 6.722 & .000 & .880 & 1.136 \\
\hline
\end{tabular}

a. Dependent Variable: Employee productivity

$\mathrm{Y}=\mathrm{B} 0+\mathrm{B} 1 \mathrm{X} 1+\mathrm{B} 2 \mathrm{X} 2+\mathrm{E}$

Whereby; $\mathrm{Y}=$ employee productivity

$\mathrm{B} 0=$ constant term

$\mathrm{B} 1$ and $\mathrm{B} 2=$ coefficient of $\mathrm{X} 1$ and $\mathrm{X} 2$ respectively

$\mathrm{X} 1=$ performance appraisal

$\mathrm{X} 2=$ performance feedback

$\varepsilon=$ error term

The linear regression model showed that when holding all factors constant (performance feedback), performance appraisal increases employee productivity by 0.245 units. Secondly, when holding all factors constant (performance appraisals), performance feedback increases employee productivity by 0.956 units.

\section{Summary of the Findings Conclusion and Recommendations}

\subsection{Performance appraisals and employee productivity}

The establishment on performance impact on performance of employee, the findings indicated that evaluation of employee causes a raise in their productivity. It was evidenced that performance appraisal makes employee work well that expected as it had a mean of 4.41 and standard deviation of 0.652 . Review of performance focuses on the engagement of employee to the firm's goals. Staffs have the chance to communicate their thoughts and their expectations in the accomplishment of the strategic goal of the firm. Performance appraisal might be an important source of managing information in decision-making. A good performance appraisal can improve the importance and employee performance causing achievement of particular work or for achieving a particular performance goal. Employee productivity had a positive association to performance appraisal with $r=0.283$.

This finding therefore indicates that performance appraisal has positive influence on employee performance. These findings agree with the findings by Brown and Benson (2013) who found that evaluation of employee performance enhanced performance procedures for the employees.

\subsection{Performance feedback and employee productivity}

The objective assessment on how performance feedback does impact employee productivity was established with strong emphasis for organizations to embrace feedback to its employees as it registered a highest mean of 4.07 and standard deviation of 0.904 . Similarly, the correlation between employee productivity and performance feedback had a strong positive $r=0.742$. 
Jackson and Schuller (2012) suggests that adequate performance feedback in the workplace helps to build responsibility, because employees and supervisors contribute in goal development, knowing your competencies, having conversation on how to develop your career and employee motivation. Nevertheless, some firms do not offer feedback. Banket (2011) explains that even some managers deliberately fail to feedback their employee; other managing work engulf the employee hence taking their precious time.

\subsection{Conclusions}

The study results showed that employee evaluation has a helpful effect on their productivity. Similarly, it found out that feedback for employee performance was positively correlated with their productivity. This was explained to result from the avenue that the employees were able to understand the organizational goals and understand areas in which they fell short to achieving the goals. It therefore provides a chance to share their thoughts and their anticipation on accomplishing the planned goals of an organization. Good appraisal system improves the employee performance and motivation causing attainment of set goal by the firm (Derven, 2015). Results of the finding showed that employees could be updated on the feedback concerning their performance at the workplace. To have a good work motivation, a manager needs to recognize employees' good performance. In addition, employees get to be creative and more innovative

\subsection{Study Recommendations}

From the foregoing, it is recommended that the management of the organization studied consider quarterly reviews and appraisal. Appraisal techniques should be diversified to include Peer appraisal, Essay appraisal and Ranking method. Equally, appraisal practices should be expanded to include 360 degrees feedback, balanced scorecard, self-review and upward reviews. Training and development programmes from various departments should be coordinated by the HR function. Appraisal feedback should take shorter periods. Development programmes should be expanded to include lower cadre employees. Other non - monetary rewards like acknowledgements, promotions to the next job group and letters of commendations should also be explored.

\subsection{Limitations of the Study}

Regardless of the study being successful, there were more shades of boundaries. Some respondents failed to unveil information needed to secure their institutions information and for securing areas known to be normally, confidential. It was not possible to verify independently, the information gives the respondents and reliability was on the officials who in any case could choose to distort information.

\subsection{Suggestions for further studies}

This study indicates that in future a study should be carried on the effect of other performance management practices on the firm's performance. In addition, it recommends that researcher in future can carry a study in the performance management practices in public organizations to compare with the findings.

\section{References}

Armstrong D. (2014). Management practices systems, Productivity, and Motivation. Public Personnel Management $31(2), 141$.

Baruch, Y. (2016). Self Performance Appraisal Vs Direct-management Appraisal: a case of congruence. Journal of Psychology 2 (10), 7-14.

Beadwell, D. (2017). Creating a Performance Culture. Thousand Oaks: CA Sage.

Bernardin, H. \&Klatt, L. (2017). Managerial Appraisal systems": Has practice "caught-up" with the state of the art? Personnel Administrator 30(2), 79-86.

Bernstein, E. S., \& Li, S. (2017). Seeing where you stand: From performance feedback to performance transparency. In Academy of Management Proceedings (Vol. 2017, No. 1, p. 14752). Briarcliff Manor, NY 10510: Academy of Management.

Bloom, W., Dorgan, F., Dowdy, V. \& van Reenen, M. (2017). Improving employee performance through appraisal and coaching (2nd ed.). New York, NY: American Management Association.

Broady-Preston, C. \& Steel, M. (2012). Can performance appraisals motivate employees to improve performance? A Mexican study. The International Journal of Human Resource Management 1 (22), 1-22. DOI:10.1080/09585192.2011.637069

Brown, M., \& Benson, J. (2013). Rated to Exhaustion? Reactions to Performance Appraisal Processes. Industrial Relations Journal 34(1), 67-81.

Caruth, C. \& Humphreys, D. (2018). Perfect phrases for performance reviews: hundreds of ready-to-use phrases that describe your employees' performance (from unacceptable to outstanding). New York: McGraw-Hill. 
Chen, L., Ellis, S. C., \& Suresh, N. (2016). A supplier development adoption framework using expectancy theory. International Journal of Operations \& Production Management, 36(5), 592-615.

Chen, Y. (2013). Self-determination in Human Behavior. Journal of Applied Psychology 74 (2), 580-590.

Cook, S. \& Crossman, M. (2014). Performance appraisal reactions: measurement, modelling and method bias. Journal of Applied Psychology 85(5), 708-723.

Erdogan, B. (2012). Antecedents and Consequences of Justice Perceptions in Performance Appraisals. Human Resource Management Review 12 (4), 555-578.

Faisal Ahammad, M., Mook Lee, S., Malul, M., \&Shoham, A. (2015). Behavioral ambidexterity: The impact of incentive schemes on productivity, motivation, and performance of employees in commercial banks. Human Resource Management, 54(S1), s45-s62.

Flake, J. K., Barron, K. E., Hulleman, C., McCoach, B. D., \& Welsh, M. E. (2015). Measuring cost: The forgotten component of expectancy-value theory. Contemporary Educational Psychology, 41, 232-244.

Fletcher, C. (2011). Performance Appraisal: How to Improve its Effectiveness. A Masters Thesis Submitted to the University of Twente, Enschede.

Gichuhi, A. W., Abaja, P.O., \&Ochieng, I. (2014). Effect of Performance Appraisal On Employee Productivity: A Case Study of Supermarkets in Nakuru Town, Kenya. Asian Journal of Business and Management Sciences 2 (11), $42-58$.

Hanaysha, J. (2016). Examining the effects of employee empowerment, teamwork, and employee training on organizational commitment. Procedia-Social and Behavioral Sciences, 229, 298-306.

Howard, L. W., Turban, D. B., \& Hurley, S. K. (2016). Cooperating teams and competing reward strategies: Incentives for team performance and firm productivity. Journal of Behavioral and Applied Management, 3(3), 1054.

Inkinen, H. (2016). Review of empirical research on knowledge management practices and firm performance. Journal of knowledge management, 20(2), 230-257. ttps://www.ijrdo.org/index.php/bm/article/view/2756

Jackson, S. \& Schuller, R. (2012). Managing Human Resources through Strategic Partnership (8th ed.). Toronto, Canada: Thompson.

Jong, J. (2016). The role of performance feedback and job autonomy in mitigating the negative effect of role ambiguity on employee satisfaction. Public Performance \& Management Review, 39(4), 814-834.

Jorgenson, B., Eisenberger, K., Rhoades, G. \& Cameron, B. (2014). Moving from Cognition to Action: A Control Theory Perspective. Applied Psychology 43(4), 335-398.

Kim, J. (2016). Impact of performance appraisal justice on the effectiveness of pay-for-performance systems after civil service reform. Public Personnel Management, 45(2), 148-170.

La Belle, B. (2015). Performance-Based Pay as a Motivational Tool for Achieving Organisational Performance: An Exploratory Case Study. International Journal of Business and Management 6 (12), 5-10.

Latham, G. P., Brcic, J., \&Steinhauer, A. (2017). Toward an integration of goal setting theory and the automaticity model. Applied Psychology, 66(1), 25-48..

Madison, J. (2016). Performance Management Revolution. Harvard Business review: October 2016 issue

Mugenda, A and Mugenda, O. (2012).Research methods dictionary. Nairobi, Kenya arts press2012.

Mugenda, A.G. (2012). Social Science Research: Theory and Principles. Nairobi: Arts Press.

Muriithi. (2015). An empirical analysis of continuing improvements following the im-plementation of a performancebased compensation plan. Journal of Accounting and Economics 30 (2), 315-350.

Okeke,M. N., Onyekwelu, N. P., Akpua, J., \&Dunkwu c. (2019). performance management and employee productivity in selected large organizations in South-East, Nigeria. IJRDO - Journal of Business Management (ISSN: 24556661), 5(3), 57-69. Retrieved from $\mathrm{h}$

Omusebe, P Musiega .J. (2013). Performance management: a strategy for improving performance and productivity. Journal of managerial psychology.

Owili,A.,\&Isaac,O.G.(2018). Organizational Justice in Performance Appraisal System and Work Performance: Evidence from an Emerging Market. Journal of Human Resources Management Research, 12(12), 1-18.

State Department for Labour (2019). Ministry of Labour and Social Protection State Department of Labour, Accessed $21^{\text {st }}$ October 2019 from <http://labour.go.ke/background/>.

Singh, P. S. P., \& Rana, S. (2015). The impact of performance appraisal on organizational commitment of bank employees. Age, 20(30), 74. 